\title{
Abbreviations and Terms
}

$\begin{array}{ll}\text { AAA } & \text { Struggle-Restoration-Independence } \\ \text { ACP } & \text { Albanian Communist Party } \\ \text { AJ } & \text { Arhiv Jugoslavije } \\ \text { AKE } & \text { Agrarian Party of Greece } \\ \text { AMFOGE } & \text { Allied Mission for Observing the Greek Elections } \\ \text { AMM } & \text { Allied Military Mission } \\ \text { Archive Marxists } & \text { KKE splinter group } \\ \text { Arvanitis } & \text { Greek Orthodox Albanians } \\ \text { ASKI } & \text { Archeia Synchronis Koinonikis Istorias } \\ \text { AYE } & \text { Istoriko Archio tou Yrourgio Exoterikon } \\ \text { BCP } & \text { Bulgarian Communist Party } \\ \text { BEF } & \text { British Expeditionary Force } \\ \text { BMM } & \text { British Military Mission } \\ \text { C } & \text { head of British Secret Intelligence Service } \\ \text { CAB } & \text { Cabinet Papers } \\ \text { CC } & \text { central committee of a communist party } \\ \text { Chrysi Avgi } & \text { Golden Dawn, an extreme right-wing party } \\ & \end{array}$




\begin{tabular}{|c|c|}
\hline Cominform & Information Bureau of communist parties \\
\hline Comintern & Third Communist International \\
\hline Committee of Six Colonels & minor resistance group in Athens \\
\hline $\cos$ & Chiefs of Staff \\
\hline CPSU & Communist Party of the Soviet Union \\
\hline CPY & Communist Party of Yugoslavia \\
\hline DAG & Democratic Army of Greece \\
\hline DGFP & Documents on German Foreign Policy \\
\hline DSE & $\begin{array}{l}\text { Democratikos Stratos Elladas (Democratic Army } \\
\text { of Greece) }\end{array}$ \\
\hline EAM & National Liberation Front \\
\hline EDES & National Democratic Greek League \\
\hline EKKA & National and Social Liberation \\
\hline ELAS & Greek Popular Liberation Army \\
\hline ELD & Union of Popular Democracy \\
\hline $\mathrm{EON}$ & Greek Youth Organization \\
\hline $\mathrm{EP}$ & National Civil Guard \\
\hline $\mathrm{FO}$ & Foreign Office (British) \\
\hline FORCE I33 & $\mathrm{SOE}$ in Greece \\
\hline FRUS & Foreign Relations of the United States \\
\hline FYROM & Former Yugoslav Republic of Macedonia \\
\hline GAK & Genika archia tou kratous \\
\hline Gendarmerie & national provincial police \\
\hline GHQ & general headquarters \\
\hline GNA & Greek National Army \\
\hline HMG & His Majesty's government \\
\hline HS & Records of Special Operations Executive \\
\hline IAEA & $\begin{array}{l}\text { Historical Archive of the National Resistance } \\
\text { (Greek) }\end{array}$ \\
\hline IDEA & Sacred Association of Nationalist Officers \\
\hline JUSMAPG & $\begin{array}{l}\text { Joint U.S. Military Advisory and Planning } \\
\text { Group_-Greece }\end{array}$ \\
\hline
\end{tabular}




\begin{tabular}{|c|c|}
\hline KKE & Communist Party of Greece \\
\hline KUTV & Communist University for Workers of the East \\
\hline $\mathrm{MI}_{5}$ & British security and counterintelligence service \\
\hline MI6 & $\begin{array}{l}\text { military designation of British Secret Intelligence } \\
\text { Service }\end{array}$ \\
\hline MI9 (N Section) & $\begin{array}{l}\text { British service assisting the escape of prisoners } \\
\text { of war }\end{array}$ \\
\hline MID & Military Intelligence Directorate (British) \\
\hline Midas 6I4 SOE & Greek espionage and sabotage group \\
\hline Military Hierarchy & monarchist faction of Greek generals in 1943 \\
\hline MIR & Military Intelligence Research \\
\hline NARA & $\begin{array}{l}\text { National Archives and Records Administration } \\
\text { (U.S.) }\end{array}$ \\
\hline $\mathrm{NOF}$ & National Liberation Front \\
\hline November I7 & Greek Marxist-Leninist Terrorist Group \\
\hline OKNE & Communist Youth of Greece \\
\hline OPLA & $\begin{array}{l}\text { Organization for the Protection of the People's } \\
\text { Struggle }\end{array}$ \\
\hline OSS & Office of Strategic Services \\
\hline OZNA & Yugoslav Secret Police \\
\hline PASOK & Panhellenic Socialist Movement \\
\hline PEAN & Panhellenic Union of Fighting Youth \\
\hline PEEA & Political Committee of National Liberation \\
\hline PESE & Philiki Etairia Stratou Eleftheroseos \\
\hline PRO & Public Records Office (UK) \\
\hline Prometheus I and II & SOE espionage network in Athens \\
\hline RG & record group \\
\hline Rimi Brigade & Greek royalist unit \\
\hline RN & Royal Navy \\
\hline Sacred Company & Greek elite company \\
\hline SAS & Special Air Service \\
\hline Section D & forerunner of SOE \\
\hline
\end{tabular}


Security Battalions

SIS

SKE

SNOF

SOE

UNRRA

USAGG

WO

X

Yiafka

YVE
German-controlled collaborationist security units

British Secret Intelligence Service (also known as MI6)

Socialist Party of Greece

Slavic National Liberation Front

Special Operations Executive (British)

United Nations Relief and Rehabilitation Agency

United States Army Group Greece

War Office

ultra-right-wing organization

communist clandestine cells

Defenders of Northern Greece 